\title{
POSSIBILITIES OF COMPLEX CONTROL OF PATHOGENS AND PEST ON TOMATO CROPS UNDER HIGH PLASTIC TUNNELS
}

\author{
G. Șovărel ${ }^{1 *}$, S.Ș. Hogea1 ${ }^{1}$, A.E. Cenușă ${ }^{1}$ and M. Costache ${ }^{1}$
}

1Research and Development Institute for Vegetable and Flower Growing Vidra, Vidra, Ilfov County, Romania

* Corresponding author: email: gabriela_sovarel@yahoo.com

\begin{abstract}
The experiment was carried out in 2020 , under high plastic tunnels conditions, using the tomato hybrid Prekos F1 and aimed to evaluate the efficacy of different combinations of fungicides with insecticides for complex control of pathogens Alternaria solani (early blight), Fulvia fulva (leaf mold) and pests Tuta absoluta (tomato leaf miner) and Helicoverpa armigera (cotton bollworm). The experimental variants were: 1 . Cabrio Top $0.2 \%+$ Coragen $0.0175 \%$; 2 . Cabrio Top $0.2 \%+$ Voliam Targo 0.08\%; 3. Dagonis $0.1 \%+$ Coragen $0.0175 \%$; 4. Dagonis $0.1 \%+$ Voliam Targo $0.08 \%$; 5 . Cidely Top $0.1 \%+$ Coragen $0.0175 \%$; 6 . Cidely Top $0.1 \%+$ Voliam Targo $0.08 \%$; 7. Ortiva Top $0.1 \%$ + Coragen $0.0175 \%$; 8. Ortiva Top $0.1 \%$ + Voliam Targo $0.08 \%$; 9. Untreated control. Six foliar treatments were applied at 10days intervals. The efficacy of these combinations of fungicides with insecticides was assessed according to the degree of attack (\%) for Alternaria solani, Fulvia fulva and Tuta absoluta or according to the frequency of the attacked fruits (\%) for Helicoverpa armigera and was between $\mathbf{8 5 . 0 \%}$ and $\mathbf{9 0 . 7 \%}$. The highest yields were registered in variants 1 (Cabrio Top $0.2 \%$ + Coragen $0.0175 \%-5,535 \mathrm{~kg} / \mathrm{m}^{2}$ ), 3 (Dagonis $0.1 \%+$ Coragen $0.0175 \%-5,440 \mathrm{~kg} / \mathrm{m}^{2}$ ) and 2 (Cabrio Top $0.2 \%+$ Voliam Targo $0.08 \%$ $5,362 \mathrm{~kg} / \mathrm{m}^{2}$ ) as compared to $4,490 \mathrm{~kg} / \mathrm{m}^{2}$ in the untreated control variant. The differences of yield, obtained in addition to the untreated control variant, were very significant in all cases.
\end{abstract}

Keywords: fungicides, insecticides, combinations, efficacy, yields

\section{INTRODUCTION}

Among the vegetable species cultivated in Romania, tomatoes occupy the first place, with 40,734 ha (FAO, 2018). From this area $\approx 8000$ ha are occupied with crops under areas (high plastic tunnels and glasshouses). Also, in this case, tomatoes are the predominant species, their cultivation being practiced on $\approx 70 \%$ of the surface in cycle I, cycle II or extended cycle.

The climatic conditions under protected areas, necessary for the growth and development of tomato plants are, at the same time, favorable for the appearance and evolution of the attack of harmful agents of economic importance, among which we mention: Alternaria solani (early blight), Botrytis cinerea (gray mold), Fulvia fulva (leaf mold), Erysiphe sp. (powdery mildew), Colletotrichum coccodes (anthracnose), Phytophthora infestans (late blight), Tuta absoluta (tomato leaf miner), Helicoverpa armigera (cotton bollworm), Macrosiphum euphorbiae (tomato aphid), Thrips tabaci (common thrips), etc. Studies undertaken worldwide and in Romania have led to the establishment of elements of epidemiology and 
bioecology of harmful organisms and, at the same time, to the development of the most appropriate control measures. In connection with foliar pathogens that attack tomato crops, strategies have been established to control them with fungicides (Miller et al., 2002; Costache et al., 2018). Regarding the Tuta absoluta and Helicoverpa armigera pests, there are numerous studies on bioecology and economic importance and the measures and means of its integrated control have been established (Desneux et al., 2010; Bratu et al., 2015; Hogea, 2020; Sene et al., 2020). The experiments carried out at ICDLF - Vidra aimed to identify combinations of fungicides with insecticides designed to control the complex of pathogens and pests present at the same time in tomato crops under high plastic tunnels.

\section{MATERIALS AND METHODS}

The experiment was carried out in 2020, under high plastic tunnels, protected with "insect proof" net, in the first cycle of crop, using the tomato hybrid Prekos F1 and included 9 experimental variants, placed according to the method of randomized blocks.

The experimental variants were:

1. Cabrio Top $0.2 \%+$ Coragen $0.0175 \%$

2. Cabrio Top $0.2 \%+$ Voliam Targo $0.08 \%$

3. Dagonis $0.1 \%+$ Coragen $0.0175 \%$

4. Dagonis $0.1 \%+$ Voliam Targo $0.08 \%$

5. Cidely Top $0.1 \%+$ Coragen $0.0175 \%$

6. Cidely Top $0.1 \%+$ Voliam Targo $0.08 \%$

7. Ortiva Top $0.1 \%+$ Coragen $0.0175 \%$

8. Ortiva Top $0.1 \%+$ Voliam Targo $0.08 \%$

9. Untreated control.

During the vegetation period, 6 foliar treatments were applied at 10-days intervals, as follows: June 12 (T1), June 22 (T2), July 2 (T3), July 13 (T4), July 23 (T5) ) and August 3 (T6). Table 1 summarizes the plant protection products used in this experiment.

Table 1. Phytosanitary products used in the experiment

\begin{tabular}{|c|c|c|c|c|}
\hline $\begin{array}{l}\text { Phytosanitary } \\
\text { products }\end{array}$ & Active ingredients & Mode of action & Pathogens and pest controled & $\begin{array}{l}\text { Break } \\
\text { time } \\
\text { (days) }\end{array}$ \\
\hline Cabrio Top & $\begin{array}{l}\text { piraclostrobin } 5 \%+ \\
\text { metiram } 55 \%\end{array}$ & $\begin{array}{l}\text { contact and } \\
\text { translaminar }\end{array}$ & $\begin{array}{l}\text { Alternaria solani, Fulvia fulva, } \\
\text { Phytophthorar infestans, } \\
\text { Leveillula taurica, Septoria } \\
\text { lycopersici }\end{array}$ & 7 \\
\hline Dagonis & $\begin{array}{l}\text { difenoconazol } 50 \mathrm{~g} / \mathrm{l}+ \\
\text { fluxapiroxad } 75 \mathrm{~g} / \mathrm{l}\end{array}$ & $\begin{array}{l}\text { contact and } \\
\text { systemic }\end{array}$ & $\begin{array}{l}\text { Alternaria solani, Fulvia fulva, } \\
\text { Leveillula taurica }\end{array}$ & 3 \\
\hline Cidely Top & $\begin{array}{l}\text { difenoconazol } 125 \mathrm{~g} / \mathrm{l} \\
\text { + ciflufenamid } 15 \mathrm{~g} / \mathrm{l}\end{array}$ & $\begin{array}{l}\text { contact and } \\
\text { systemic }\end{array}$ & $\begin{array}{l}\text { Alternaria solani, Fulvia fulva, } \\
\text { Leveillula taurica }\end{array}$ & 3 \\
\hline Ortiva Top & $\begin{array}{l}\text { azoxistrobin } 200 \mathrm{~g} / \mathrm{l}+ \\
\text { difenoconazol } 125 \mathrm{~g} / \mathrm{l}\end{array}$ & $\begin{array}{l}\text { contact and } \\
\text { systemic }\end{array}$ & $\begin{array}{lrr}\begin{array}{l}\text { Alternaria } \\
\text { cinerea, }\end{array} \text { Fulvia } & \begin{array}{r}\text { Botrytis } \\
\text { fulva, } \\
\text { Phytophthora } \\
\text { infestans, }\end{array} \\
\text { Leveillula taurica } & \\
\end{array}$ & 7 \\
\hline Coragen & clorantraniliprol 20\% & $\begin{array}{l}\text { local systemic } \\
\text { and translaminar }\end{array}$ & $\begin{array}{l}\text { Tuta absoluta, Helicoverpa } \\
\text { armigera }\end{array}$ & 1 \\
\hline Voliam Targo & $\begin{array}{c}\text { abamectin } 18 \mathrm{~g} / \mathrm{l}+ \\
\text { clorantraniliprol } 45 \mathrm{~g} / \mathrm{l}\end{array}$ & $\begin{array}{l}\text { local systemic } \\
\text { and translaminar }\end{array}$ & $\begin{array}{l}\text { Tuta absoluta, Helicoverpa } \\
\text { armigera, Liriomyza sp., } \\
\text { Tetranychus urticae }\end{array}$ & 3 \\
\hline
\end{tabular}


During the vegetation period, dynamic observations were made on the appearance and evolution of the attack of pathogens and pests (frequency and intensity of attack) in correlation with climatic factors, and finally the degree of attack was calculated (\%; for Alternaria solani, Fulvia fulva, Tuta absoluta) or frequency of fruits attack (\%; for Helicoverpa armigera) and efficacy (\%) of combinations of plant protection products used to control harmful organisms.

The yield was also harvested in dynamics, on variants and repetitions, and the obtained data were processed by the method of analysis of variance.

\section{RESULTS AND DISCUSSIONS}

The attack of the pathogens Alternaria solani, Fulvia fulva and the pests Tuta absoluta (fig. 1 and 2) and Helicoverpa armigera appeared and evolved in the tomato crop.

The attack produced by Alternaria solani appeared on May 22 and evolved slowly so that, in the first decade of August, the degree of attack reached 8.2\% (Table 2). The Fulvia fulva attack started on May 28, the value of the degree of attack reaching 31.2\% at the end of the first decade of August. The attack was favored by high average temperatures $\left(27.9-29.9^{\circ} \mathrm{C}\right)$ and maximum relative humidity over $90 \%$.

Table 2. The appearance and evolution of the attack of pathogens and pests in correlation with climatic factors

\begin{tabular}{|c|c|c|c|c|c|c|c|c|c|c|}
\hline \multirow{4}{*}{$\begin{array}{l}\text { Pathogens/Pests/ } \\
\text { climatic factors }\end{array}$} & \multirow{4}{*}{$\begin{array}{c}\text { Date of } \\
\text { attack } \\
\text { appearance }\end{array}$} & \multicolumn{9}{|c|}{ Degree of attack (\%) / attack frequency (\%) } \\
\hline & & \multirow{2}{*}{\multicolumn{2}{|c|}{$\begin{array}{c}\text { May } \\
\text { Decade }\end{array}$}} & \multirow{2}{*}{\multicolumn{3}{|c|}{$\frac{\text { June }}{\text { Decade }}$}} & \multirow{2}{*}{\multicolumn{3}{|c|}{$\frac{\text { July }}{\text { Decade }}$}} & August \\
\hline & & & & & & & & & & Decade \\
\hline & & II & III & I & II & III & I & II & III & I \\
\hline Alternaria solani & 22.05 & 0 & 0.2 & 0.6 & 1.7 & 2.9 & 3.6 & 4.2 & 6.7 & 8.2 \\
\hline Fulvia fulva & 28.05 & 0 & 0.4 & 0.8 & 1.7 & 3.9 & 9.6 & 15.8 & 23.3 & 31.2 \\
\hline Tuta absoluta & 14.05 & 0.9 & 1.5 & 3.8 & 6.1 & 10.2 & 17.3 & 28.7 & 35.4 & 40.6 \\
\hline Helicoverpa armigera & 22.06 & 0 & 0 & 0 & 0 & 0.6 & 1.2 & 2.9 & 4.7 & 7.8 \\
\hline $\begin{array}{l}\text { Minimum } \\
\text { temperature }\left({ }^{\circ} \mathrm{C}\right)\end{array}$ & - & 14.5 & 10.4 & 12.2 & 16.8 & 16.3 & 17.9 & 15.5 & 18.1 & 17.6 \\
\hline $\begin{array}{l}\text { Average temperature } \\
\left({ }^{\circ} \mathrm{C}\right)\end{array}$ & - & 26.1 & 20.2 & 23.5 & 24.9 & 27.9 & 29.7 & 27.0 & 29.6 & 29.9 \\
\hline $\begin{array}{l}\text { Maximum } \\
\text { temperature }\left({ }^{\circ} \mathrm{C}\right)\end{array}$ & - & 39.4 & 34.5 & 37.2 & 37.8 & 40.6 & 41.7 & 39.6 & 43.0 & 42.2 \\
\hline $\begin{array}{l}\text { Minimum humidity } \\
(\%)\end{array}$ & - & 25.2 & 31.8 & 30.4 & 42.1 & 30.2 & 25.8 & 24.8 & 24.6 & 18.6 \\
\hline Average humidity (\%) & - & 54.6 & 66.1 & 64.3 & 74.8 & 62.7 & 55.9 & 54.8 & 58.7 & 44.4 \\
\hline $\begin{array}{l}\text { Maximum humidity } \\
(\%)\end{array}$ & - & 86.2 & 93.1 & 93.7 & 96.7 & 93.9 & 89.9 & 88.3 & 91.9 & 77.9 \\
\hline
\end{tabular}

Among the pests was the earliest attack of Tuta absoluta (May 14) which evolved rapidly due to high average temperatures $\left(27.9-29.9^{\circ} \mathrm{C}\right)$, from the third decade of June - the first decade of August, reaching at $40.6 \%$. The latest attack was the pest Helicoverpa armigera (June 22), the frequency of the attack reaching $7.8 \%$, at the end of the first decade of August.

The average efficacy of the combinations of fungicides with insecticides experimented for the complex control of pathogens and pests was between $85.2 \%$ (variant 8: Ortiva Top 0.1\% + Voliam Targo 0.08\%) and 90.7\% (variant 1: Cabrio Top 0.2\% + Coragen 0.0175\%; table 3). Based on the results obtained, it can be appreciated that practically all the combinations tried ensured a good protection of the tomato plants against 
the attack of the pathogens Alternaria solani, Fulvia fulva and the pests Tuta absoluta and Helicoverpa armigera.

Regarding the obtained yield, it varied between $5.105 \mathrm{~kg} / \mathrm{m}^{2}$ (V6) and $5.535 \mathrm{~kg} / \mathrm{m}^{2}$ (V1) as compared to $4.490 \mathrm{~kg} / \mathrm{m}^{2}$ in the untreated control variant (Table 4). The highest yields were registered at variants $1\left(5.535 \mathrm{~kg} / \mathrm{m}^{2}\right), 3\left(5.440 \mathrm{~kg} / \mathrm{m}^{2}\right)$ and $2\left(5.362 \mathrm{~kg} / \mathrm{m}^{2}\right)$. The yield differences obtained in addition to the untreated control variant, varied between $0.615 \mathrm{~kg} / \mathrm{m}^{2}$ at V6 and $1.045 \mathrm{~kg} / \mathrm{m}^{2}$ at V1 are very significant.

Table 3. Efficacy of product combinations in the complex control of pathogens and pests on tomato crop under high plastic tunnels

\begin{tabular}{|c|c|c|c|c|c|c|c|c|c|}
\hline \multirow[t]{2}{*}{ Variant } & \multicolumn{3}{|c|}{$\begin{array}{c}\text { Degree of attack } \\
\text { (\%) }\end{array}$} & \multirow{2}{*}{\begin{tabular}{|c|}
$\begin{array}{c}\text { Frequency } \\
\text { of attack } \\
(\%)\end{array}$ \\
\\
\\
$\frac{5}{0}$
\end{tabular}} & \multicolumn{4}{|c|}{$\begin{array}{l}\text { Eficacy } \\
(\%)\end{array}$} & \multirow{2}{*}{$\begin{array}{c}\text { Average } \\
\text { efficacy } \\
(\%)\end{array}$} \\
\hline & $\stackrel{n}{\vdots}$ & $\sum^{2}=$ & 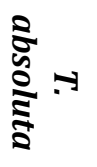 & & $\stackrel{\mathscr{s}}{\mathfrak{s}}$ & 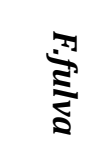 & $\begin{array}{l}\frac{2}{2} \\
\frac{\pi}{5} \\
0\end{array}$ & $\frac{\sqrt[5]{0}}{\frac{5}{3}}=$ & \\
\hline $\begin{array}{l}\text { 1. Cabrio Top } 0.2 \% \\
\text { + Coragen } 0.0175 \%\end{array}$ & 0 & 3.5 & 3.2 & 1.4 & 100.0 & 88.8 & 92.1 & 82.0 & 90.7 \\
\hline $\begin{array}{l}\text { 2. Cabrio Top } 0.2 \% \\
+\quad \text { Voliam } \\
0.08 \%\end{array}$ & 1.2 & 3.8 & 5.2 & 1.6 & 85.4 & 87.8 & 87.2 & 79.5 & 85.0 \\
\hline $\begin{array}{l}\text { 3. Dagonis } 0.1 \%+ \\
\text { Coragen } 0.0175 \%\end{array}$ & 0 & 3.6 & 3.8 & 1.6 & 100.0 & 88.5 & 90.6 & 79.5 & 89.6 \\
\hline $\begin{array}{l}\text { 4. Dagonis } 0.1 \%+ \\
\text { Voliam Targo } 0.08 \%\end{array}$ & 0 & 4.0 & 4.6 & 2.2 & 100.0 & 87.2 & 88.7 & 71.8 & 86.9 \\
\hline $\begin{array}{l}\text { 5. Cidely Top } 0.1 \% \\
\text { + Coragen } 0.0175 \%\end{array}$ & 1.4 & 3.8 & 3.1 & 1.4 & 82.9 & 87.8 & 92.4 & 82.0 & 86.3 \\
\hline $\begin{array}{l}\text { 6. Cidely Top } 0.1 \% \\
+\quad \text { Voliam } \\
0.08 \%\end{array}$ & 0 & 5.1 & 4.5 & 1.3 & 100.0 & 83.6 & 88.9 & 83.3 & 88.9 \\
\hline $\begin{array}{l}\text { 7. Ortiva Top } 0.1 \% \\
+ \text { Coragen } 0.0175 \%\end{array}$ & 1.6 & 6.1 & 3.9 & 0 & 80.5 & 80.4 & 90.4 & 100,0 & 87.8 \\
\hline $\begin{array}{l}\text { 8. Ortiva Top } 0.1 \% \\
+\quad \text { Voliam } \\
0.08 \%\end{array}$ & 1.2 & 5.4 & 3.3 & 1.5 & 85.4 & 82.7 & 91.9 & 80.8 & 85.2 \\
\hline 9. Martor netratat & 8.2 & 31.2 & 40.6 & 7.8 & - & - & - & - & - \\
\hline
\end{tabular}


Table 4. The influence of treatments with combinations of fungicides and insecticides on tomato yield under high plastic tunnels (Prekos F1 hybrid)

\begin{tabular}{|c|c|c|c|c|}
\hline Variant & Yield $\left(\mathrm{kg} / \mathrm{m}^{2}\right)$ & Relative yield (\%) & $\begin{array}{c}\text { Difference from control } \\
\left(\mathrm{kg} / \mathrm{m}^{2}\right)\end{array}$ & Significance \\
\hline 1 & 5.535 & 123.2 & +1.045 & $* * *$ \\
\hline 2 & 5.362 & 119.4 & +0.872 & ${ }^{* * *}$ \\
\hline 3 & 5.440 & 121.1 & +0.950 & ${ }^{* * *}$ \\
\hline 4 & 5.308 & 118.2 & +0.818 & ${ }^{* * *}$ \\
\hline 5 & 5.155 & 114.8 & +0.665 & ${ }^{* * *}$ \\
\hline 6 & 5.105 & 113.6 & +0.615 & ${ }^{* * *}$ \\
\hline 7 & 5.355 & 119.2 & +0.865 & ${ }^{* * *}$ \\
\hline 8 & 5.260 & 117.1 & +0.770 & - \\
\hline 9 & 4.490 & 100.0 & - & \\
\hline
\end{tabular}

DL $5 \%=0.30 ;$ DL $1 \%=0.42 ;$ DL $0,1 \%=0.56$

\section{CONCLUSIONS}

In the first cycle, the attack of the pathogens Alternaria solani, Fulvia fulva and the pests Tuta absoluta and Helicoverpa armigera was manifested in the tomato crop under high plastic tunnels.

The efficacy of the combinations of fungicides with experiented insecticides, used to complex control of harmful organisms varied between $85.2 \%$ (V 8: Ortiva Top $0.1 \%+$ Voliam Targo 0.08\%) and 90.7\% (V1: Cabrio Top 0.2\% + Coragen $0.0175 \%$ ).

The highest yields were registered for variants 1 (Cabrio Top $0.2 \%+$ Coragen $0.0175 \%$; $5.535 \mathrm{~kg} / \mathrm{m}^{2}$ ), 3 (Dagonis 0.1\% + Coragen 0.0175\%; $5.440 \mathrm{~kg} / \mathrm{m}^{2}$ ) and 2 (Cabrio Top 0.2\% + Voliam Targo $0.08 \% ; 5.362 \mathrm{~kg} / \mathrm{m}^{2}$ ).

The yield differences obtained in addition to the untreated control variant were, in all cases, very significant.

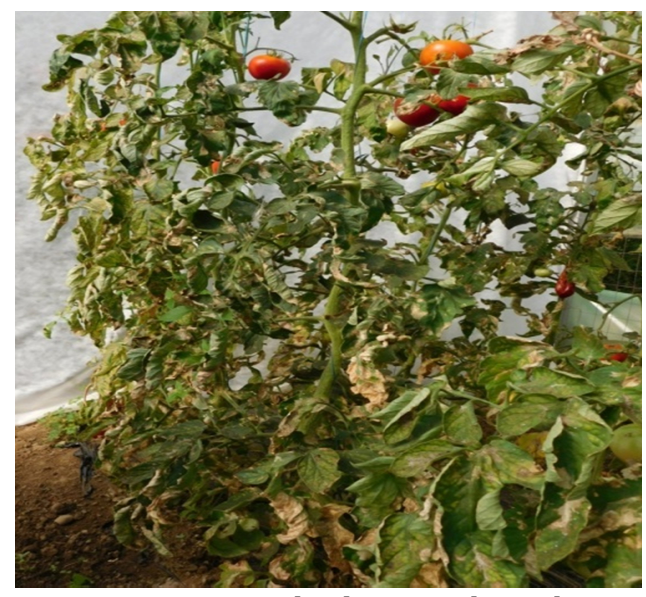

Figure 1. Tuta absolutaattack on the untreated control

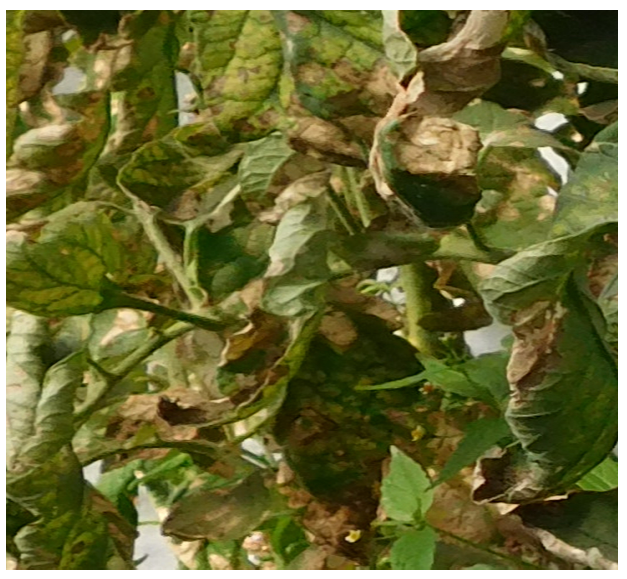

Figure 2. Fulvia fulva and Tuta absoluta attack on the untreated control 


\section{REFERENCES}

1. Bratu, E., Petcuci, A.M., Șovărel, G. (2015). Efficacy of the Product Spinosad an Insecticide Used in the Control of Tomato Leafminer (Tuta absoluta - Meyrick, 1917). BulletinUASVM Horticulture, 72(1), DOI:10.15835/buasvmcn-hort:10876.

2. Costache M., Șovărel G., Bratu E. Bolile și dăunătorii culturilor de legume din spații protejate -recunoaștere și combatere. Editura Ceres, București, 2018, pp. 33-38, 59-64.

3. Desneux, N., Wajnberg, E., Wyckhuys, K.A.G., Burgio, G., Arpaia, S., Narvaez-Vasquez, C.A., Gonzalez-Cabrera, J., Ruescas D.C., Tabone, E., Frandon, J., Pizzol, J., Poncet, C., Cabello, T., Urbaneja, A. (2010). Biological invasions of European tomato crops by Tuta absoluta: ecology, geographic expansion and prospects for biological control. J. Pest. Sci. 83:197-215.

4. Hogea, S.S. (2020). Tuta absoluta (Meyrick) (Lepidoptera: Gelechiidae) - biology, ecology, prevention and control measures and means in greenhouse tomato crops. A review. Current Trends in Natural Sciences, Vol. 9, Issue 17, pp. 222-231.

5. Miller, D.J., Coffman, C.B., Teasdale, J.R., Everts, K.L., Abdul-Baki, A.A., Lydon, J., and Anderson, J.D., (2002). Foliar disease in fresh-market tomato grown in differing bed strategies and fungicide spray programs. Plant Disease 86: 955-959.

6. Sene, S.O., Tendeng, E., Diatte, M., Sylla, S., Labou, B., Diallo, A.W., Diarra, K. (2020). Insecticide resistance in field of the tomato fruitworm, Helicoverpa armigera, from Senegal. Int. J. Biol. Chem. Sci. 14(1): 181-191, ISSN 1997-342X. 